PEDAGOGIEK

www.pedagogiek-online.nl

Uitgave: Amsterdam University Press

\title{
Een nieuwe uitgever, een vernieuwd elan
}

\author{
Joep Bakker
}

PED 36 (1): 1-3

DOI: 10.5117/PED2016.1.BAKK

Voor u ligt de nieuwste aflevering van het tijdschrift Pedagogiek, om nauwkeurig te zijn, nummer 1 van de $36^{\mathrm{e}}$ jaargang. Afgezien van de inhoud, verschilt het in vorm van die van vorige jaargangen. De bladspiegel is anders, evenals het lettertype en, het meest in het oog springend, de omslag. Deze wijzigingen in vormgeving zijn gevolg van de overstap van uitgeverij Van Gorcum naar een nieuwe, Amsterdam University Press. Vormde de samensmelting van de voormalige tijdschriften Comenius (1980) en het Tijdschrift voor Opvoeding, Vorming en Onderwijs (1985) tot het huidige Pedagogiek de eerste belangrijke transitie van ons tijdschrift, de overgang naar een nieuwe uitgever lijkt in haar bijna zesendertig jarig bestaan een belangrijke tweede.

Er mag dan een en ander aan het uiterlijk veranderd zijn, de beoogde doelen van Pedagogiek blijven dezelfde. Het tijdschrift stelt zich ten doel de wetenschappelijke discussie over opvoeding, onderwijs en vorming binnen het Nederlands taalgebied te stimuleren en te ondersteunen. Behalve aan het wetenschappelijk debat wil Pedagogiek ook uitdrukkelijk een bijdrage aan het maatschappelijk debat leveren. Het jaarlijks uitgebrachte themanummer getuigt daarvan, maar ook in de reguliere afleveringen verdient het maatschappelijk debat een plaats; misschien wel een prominenter dan tot dusver het geval was. En laten we wel zijn, aanleiding is er te over. Denk bijvoorbeeld maar aan het door staatssecretaris Dekker omarmde advies van het Platform Onderwijs 2032 om het hele curriculum van zowel basisonderwijs als voortgezet onderwijs op de schop te nemen en het onderwijs voortaan vakoverstijgend in te richten. Daarbij zouden bovendien, zoals in het advies staat, 'mogelijkheden en interesses van de leerlingen als leidraad dienen' zodat zij zich 'als persoon vormen waar het gaat om de ontwikkeling van hun identiteit, hun creativiteit en levensstijl' (sic). Het gaat me nu niet om het slechte Nederlands, wel om het feit dat de 
plannen elke wetenschappelijke onderbouwing missen. En dat bevreemdt des te meer indien men zich realiseert dat diezelfde staatssecretaris vorig jaar nog elk anti-pestprogramma dat niet evidence based was, naar de prullenbak verwees, daarmee menig leerkracht tegen zich in het harnas jagend.

Of denk aan de vele rapporten die het bureau van de Kinderombudsman recent publiceerde, waarin o.m. het soms door leraren afgedwongen ritalingebruik van leerlingen werd gehekeld, de inrichting van het passend onderwijs ter discussie werd gesteld, de opvang en behandeling van vluchtelingenkinderen werd bekritiseerd en, als gevolg van de decentralisatie van de zorg naar de gemeenten, de toegankelijkheid en kwaliteit van de jeugdhulp als ver onder de maat werden beoordeeld.

Als ik dit schrijf liggen de aanslagen in Brussel nog vers in het geheugen. Avond aan avond verschenen er zogeheten terreurdeskundigen op de TV om hun licht op de gebeurtenissen te laten schijnen. Heel veel wijzer werd ik er niet van, temeer daar ze elkaar nogal eens tegenspraken. Maar in één opzicht bleken ze gelijk gestemd; daar waar ze ter preventie van radicalisering c.q. jihadisering een rol aan de wijkagent, maar een nog belangrijkere rol aan opvoeding en onderwijs, gezin en school toekenden. Hoe een en ander dan gestalte zou moeten krijgen bleef echter telkenmale in duister gehuld; daar werd de deskundigen trouwens nooit naar gevraagd. En dan miste ik een pedagoog of psycholoog aan zo'n tafel van Nieuwsuur of Pauw die op basis van onderzoek of theoretisch inzicht enige helderheid over de rol van opvoeding en onderwijs ter zake kon verschaffen. Onwillekeurig moest ik denken aan een figuur, opgenomen in het artikel dat Orhan Agirdag en zijn collega's in 2012 voor het themanummer Cultureel-etnische diversiteit in maatschappij en onderwijs schreven over de segregatie in het Vlaamse basisonderwijs. Daaruit valt op te maken dat naarmate de schoolsegregatie toeneemt, kinderen uit etnische minderheidsgroepen zich minder 'Belg' voelen.

Zo'n constatering lijkt tegen de achtergronden van de aanslagen in Brussel en Parijs ineens een extra dimensie te krijgen. Het laat zich althans denken dat daar, waar identificatie met het thuisland ontbreekt, het verlangen naar een alternatief doet groeien. Staat dat die kinderen nog niet helder voor ogen, voor jeugdigen kan er al gauw een lonkend perspectief ontstaan dat hen tezelfdertijd een identiteit verschaft. 'Explosief materiaal' noemt terreurexpert Knoope dat in een interview in het novembernummer van het Belgische opinieblad Knack. En dat helpt misschien ook verklaren waarom sommige kinderen op basisscholen in de Haagse Schilderswijk 
hun enthousiasme nauwelijks konden onderdrukken toen hun leraar het nieuws over de aanslagen in Parijs en Brussel met hen deelde.

Het zijn maar wat voorbeelden van maatschappelijk relevante problematiek. Ongetwijfeld zijn er andere voorbeelden aan de orde te stellen. Maar wat zou het mooi zijn wanneer in de kolommen van dit tijdschrift voluit over deze en andere maatschappelijke kwesties werd gediscussieerd. Hetzij op basis van gedegen empirisch onderzoek, dan wel op basis van doorwrochte theoretische kennis. Ik vat de overstap naar een nieuwe uitgever als een extra uitnodiging daartoe op. Een nieuwe uitgever, een vernieuwd elan; laten we het daarop houden.

E-mail: j.bakker@pwo.ru.nl 
